\title{
Modification of glucocorticoid-induced changes in myofibrillar protein turnover in rats by protein and energy deficiency as assessed by urinary excretion of $N^{\top}$-methylhistidine
}

\author{
By F. M. TOMAS, A. J. MURRAY AND L. M. JONES \\ CSIRO Division of Human Nutrition, Kintore Avenue, Adelaide, \\ South Australia 5000, Australia
}

(Received 12 August 1983 - Accepted 1 November 1983)

1. The effects of differing degrees of experimental protein-energy malnutrition on the response of myofibrillar protein turnover rates to administration of corticosteroid has been studied in two experiments on rats. The basal control diet, offered ad lib. in each case, contained $40 \mathrm{~g}$ protein $/ \mathrm{kg}$, and other groups received diets containing $62.5,95$ or $220 \mathrm{~g}$ protein $/ \mathrm{kg}$ at $\mathbf{0 . 6 7 , 1}$ or 1.5 times the level of the control energy intake.

2. Daily administration of 25 or $30 \mathrm{mg}$ corticosterone/ $\mathrm{kg}$ body-weight after $18 \mathrm{~d}$ pre-feeding caused an increase in plasma protein, glucose and insulin concentrations, but a decrease in the corticosterone:insulin values. Liver size and protein content increased, as did the fractional excretion of dietary nitrogen as urea- $\mathrm{N}$ in all treated groups. However, whereas a fall in food intake and body-weight occurred in one experiment the reverse occurred in the other.

3. $N^{\top}$-Methylhistidine excretion was $12 \%$ lower for rats receiving $40 v .220 \mathrm{~g}$ protein $/ \mathrm{kg}$ diet and excretion was increased by only $57 \mathrm{v} .90 \%$ respectively, when the two groups of rats were given $30 \mathrm{mg}$ corticosterone $/ \mathrm{kg}$ per d. Rats which received $25 \mathrm{mg}$ corticosterone $/ \mathrm{kg}$ per $\mathrm{d}$ and up to $95 \mathrm{~g}$ protein $/ \mathrm{kg}$ diet increased excretion of $N^{\top}$-methylhistidine by an average $35 \%$.

4. The fractional degradation rate of myofibrillar protein $\left(k_{d}\right)$ was reduced by about $10 \%$ by the low-protein diet from 3.1 to $2.8 \% / \mathrm{d}$. During corticosterone treatment the increment in $k_{d}$ for rats on this diet was only $60 \%$ of that for rats receiving the $220 \mathrm{~g}$ protein $/ \mathrm{kg}$ diet, i.e. an increase of 1.8 v. $3.0 \% / \mathrm{d}$. Energy restriction further reduced $k_{d}$ during low-protein intake but did not affect the response to the corticosterone. Variations in dietary protein from 40 to $95 \mathrm{~g} / \mathrm{kg}$ had little effect on the increase in $k_{d}$ during steroid treatment. The effect of corticosterone on calculated synthesis rates $\left(k_{g}\right)$ differed markedly between experiments. While $k_{8}$ fell by $50-65 \%$ in rats which lost weight on treatment, it rose by up to $60 \%$ in rats where carcass non-collagen-protein accretion remained unchanged or increased, despite an increase in $k_{d}$.

5. Protein deficiency decreases the catabolic response to glucocorticoid, but the net metabolic response appears crucially dependent on changes in food intake or the stage of growth of the rat or both. A net anabolic response with increased fractional rates of myofibrillar protein breakdown, synthesis and accretion was observed in growing rats fed on relatively-low-protein diets and given $25 \mathrm{mg}$ corticosterone $/ \mathrm{kg}$ per $\mathrm{d}$. This novel finding indicates that a particular role for cortisol in the adaptation to protein-energy malnutrition by humans should be ascribed only with caution.

The role of glucocorticoids in the aetiology of protein-energy malnutrition remains unclear. There is evidence in humans that the spectrum of sequelae from marasmus to kwashiorkor may be correlated with a range of adrenal corticosteroid secretory activities, and that the development of kwashiorkor is due to failure of the adrenals to increase secretion. Thus the body does not adapt by losing muscle mass in order to maintain plasma protein levels and thereby prevent oedema (Jaya Rao, 1974). While this concept is now regarded as too simplistic (Coward \& Lunn, 1981; Golden, 1982) and it is accepted that the pathogenesis of protein-energy malnutrition sequelae is multifactorial, sufficient evidence exists to suggest that maintenance of relatively low corticosteroid levels may play an important role in the development of kwashiorkor. For example, Whitehead \& Lunn (1979) and Smith et al. (1981) have reported results which show that kwashiorkor is associated with lower levels of plasma cortisol than is marasmus.

Experimentally, administration of cortisone to protein-deficient rats leads to an increase in plasma albumin levels and liver protein content, coincidentally with a loss of muscle 
protein (Lunn et al. 1976). Goodlad \& Munro (1959) have shown earlier that administration of cortisone to rats receiving different levels of protein and energy increases liver protein content but also increases the net loss of nitrogen from the body. The catabolic effect of the hormone appeared independent of the nutritional state of the animal, but the animals were not given the deficient diets before treatment. Also the doses administered were relatively high and the comparative changes in muscle protein synthesis and breakdown rates were not determined. Recently, Santidrian et al. (1981), using a similar experimental regimen to that of Goodlad \& Munro (1959), found that rats fed on energy-deficient diets are more sensitive than protein-deficient rats to simultaneous treatment with glucocorticoid as assessed by $N^{\tau}$-methylhistidine excretion.

Both malnutrition (protein deficiency) and exogenously administered glucocorticoids are known to cause a reduction in the rate of protein synthesis and the RNA content of muscle (Waterlow et al. 1978). However, whether the reduced protein synthesis in malnutrition is partially mediated by a secondary rise in corticosterone levels (or corticosterone:insulin value) is not clear. The muscle is possibly less sensitive to glucocorticoids during malnutrition, and this may be expressed as a relative resistance to increased muscle protein breakdown at a particular level of hormone.

We have tested the effect of protein and energy deficiency states on the catabolic effects of corticosterone, especially on the changes in the rate of protein breakdown as monitored by the excretion of $N^{T}$-methylhistidine. The results indicate that the nutritional state can affect the response to exogenous glucocorticoid administration. Malnutrition decreases the efficacy of this hormone in respect of enhancement of myofibrillar protein breakdown, and increases the efficiency of re-utilization of that $\mathbf{N}$ which is released from muscle.

\section{METHODS}

\section{Expt 1}

Thirty male hooded rats of $140-150 \mathrm{~g}$ body-weight were used in the experiment. The rats were housed individually in metabolism cages to enable control of the food intake and collection of urine and faeces. Initially twenty rats were placed in metabolism cages and given a diet containing $220 \mathrm{~g}$ casein $/ \mathrm{kg}$. After $4 \mathrm{~d}$ of adaptation to the diet, ten rats were given ad lib. a diet containing $40 \mathrm{~g}$ casein $/ \mathrm{kg}$ while the remaining rats received matched intakes of the $220 \mathrm{~g}$ protein $/ \mathrm{kg}$ diet at 10.00 hours daily. Details of the diets are given in Table 1.

After $14 \mathrm{~d}$ of giving the low-protein diet, daily urine collection was begun. After a further $3 \mathrm{~d}$, five rats from each diet group were injected subcutaneously with $30 \mathrm{mg}$ corticosterone $/ \mathrm{kg}$ body-weight each day for $7 \mathrm{~d}$ just before feeding. From previous experience this dose was expected to produce growth stasis. This point of balance between anabolic and catabolic influences was felt to be a suitable and reproducible physiological state to investigate nutritional modification of glucocorticoid effects. The remaining rats received injection of vehicle only, as described previously (Tomas, 1982).

Urine collections $(24 \mathrm{~h}$ ) were made for $3 \mathrm{~d}$ before injections to the end of the experiment. Thymol was used as a preservative and the collection funnels were carefully rinsed at the end of each day. Trunk blood was collected at the end of the experiment on decapitation of the animals, after which the liver and gastrocnemius muscles were removed, weighed and stored at $-20^{\circ}$.

At a later date, two groups of five rats of $140-150 \mathrm{~g}$ body-weight were placed in metabolic cages and given either one of the experimental diets in quantities exactly matched to the daily intakes of the experimental groups described previously, during the period before corticosterone injection. They were then killed and the carcass prepared as described in Expt 2 for analysis of body composition. 
Table 1. Composition of diets given to rats $(\mathrm{g} / \mathrm{kg})$

\begin{tabular}{|c|c|c|c|c|c|}
\hline \multirow{2}{*}{$\frac{\text { Constituent }}{\text { Casein (protein) }}$} & \multicolumn{2}{|c|}{ Expt 1} & \multicolumn{3}{|c|}{ Expt 2} \\
\hline & 40 & 220 & 40 & $62 \cdot 5$ & 95 \\
\hline DL-Methionine & 0.56 & 3.0 & 0.56 & 0.87 & 1.33 \\
\hline Starch & 660 & 500 & 660 & 638 & 605 \\
\hline Sucrose & 197 & 175 & 197 & 197 & 197 \\
\hline Peanut oil & 20 & 20 & 50 & 50 & 50 \\
\hline Cod-liver oil* & 30 & 30 & - & - & _- \\
\hline Halibut oil $\dagger$ & - & - & 0.4 & 0.4 & 0.4 \\
\hline Mineral mixture $\ddagger$ & 50 & 50 & 50 & 50 & 50 \\
\hline Vitamin mixture\$ & 1 & 1 & 1 & 1 & 1 \\
\hline Choline chloride & 1 & 1 & 1 & 1 & i \\
\hline
\end{tabular}

* Provides not less than $65 \mu \mathrm{g}$ cholecalciferol and $6 \mathrm{mg}$ retinol $/ \mathrm{kg}$ diet.

$\uparrow$ Provides $30 \mu \mathrm{g}$ cholecalciferol and $3.6 \mathrm{mg}$ retinol $/ \mathrm{kg}$ diet.

† Rogers \& Harper (1965).

$\S$ Provides (mg/kg diet): thiamin hydrochloride 70 , riboflavin 30 , nicotinamide 50 , calcium pantothenate 150 , pyridoxal hydrochloride 15 , inositol $400, p$-aminobenzoic acid 50 , folic acid 10 , biotin $0 \cdot 4$, cyanocobalamin $0 \cdot 02$.

$N^{\tau}$-methylhistidine concentrations in urine were determined on an amino acid analyser (JEOL JA6) after preparation of the samples as described earlier (Tomas et al. 1979). Urinary creatinine and urea concentrations were determined on daily samples by using Technicon AutoAnalyzer methods (Technicon Instruments Co. Ltd, 1965, 1967 respectively). Plasma albumin was assayed by a dye-binding method using bromcresol green (Webster, 1977). Protein determinations on plasma and powdered liver samples were made by the method of Lowry et al. (1951) adapted for autoanalysis, and on powdered muscle and carcass samples by the heated Biuret method of Dorsey et al. (1977) with crystalline bovine albumin as the standard. Glucose concentrations in plasma were assayed with a hexokinase (EC2 .7 . 1 1) method ('Glucoquant';Boehringer, Mannheim). Plasma insulin was measured with a radioimmunoassay kit (Amersham IM78; Amersham International, Bucks) and plasma corticosterone was measured by radioimmunoassay with an antibody to corticosterone obtained from Endocrine Sciences (Tarzana, California).

\section{Expt 2}

Fifty-two male hooded rats of $70-80 \mathrm{~g}$ body-weight were used. Twenty rats were placed in metabolism cages and given a diet containing $95 \mathrm{~g}$ protein $/ \mathrm{kg}$ for $3 \mathrm{~d}$, after which groups of four animals were given the following diets for 3 weeks: $40 \mathrm{~g}$ protein $/ \mathrm{kg}$, ad lib. (control group); $62.5 \mathrm{~g}$ protein $/ \mathrm{kg}$, restricted to maintain isonitrogenous intake; $62.5 \mathrm{~g}$ protein $/ \mathrm{kg}$, restricted to maintain isoenergetic intake; $95 \mathrm{~g}$ protein $/ \mathrm{kg}$, restricted to maintain energy and $\mathrm{N}$ intake levels of the isonitrogenous and isoenergetic diets respectively and $62.5 \mathrm{~g}$ protein $/ \mathrm{kg}$, fed to allow $50 \%$ greater energy intake. The relative protein:energy values of these dietary regimens were $1: 1,1: 0 \cdot 7,1 \cdot 6: 1,1 \cdot 6: 0 \cdot 7$ and $2 \cdot 3: 1.5$ respectively. A further sixteen rats were held concurrently in individual cages. Of these animals, eight received the $40 \mathrm{~g}$ protein $/ \mathrm{kg}$ diet ad lib. and eight the $62.5 \mathrm{~g}$ protein $/ \mathrm{kg}$ diet at isonitrogenous intake. The remaining sixteen rats were placed in the metabolism cages after completion of observations on the other rats, and groups of four were given the experimental diets (except the $62.5 \mathrm{~g}$ protein $/ \mathrm{kg}$ at isonitrogenous intake) in quantities exactly matched to those of the appropriate experimental group during the previous pre-feeding period.

After the 3 weeks pre-feeding period, these thirty-two control rats were killed to provide baseline values for the five experimental groups which remained in metabolism cages and 
received a daily subcutaneous injection of $25 \mathrm{mg}$ corticosterone $/ \mathrm{kg}$ body-weight for $7 \mathrm{~d}$. As in Expt 1, this dose was expected to produce growth stasis in these particular rats. Urine was collected before and during treatment. At the completion of the experiment the rats were decapitated, trunk blood collected and the liver removed as in Expt 1. The carcass was prepared by removal of the skin, viscera, feet, head and most of the tail. Dissection and analysis of rats in our laboratory showed this carcass preparation to contain $85.0 \%$ (SE $0.5, n$ ) of total skeletal muscle and $88.9 \%$ of total non-collagen-protein. The carcass was weighed and stored at $-20^{\circ}$. Samples were analysed as in Expt 1, except that urinary $N^{\top}$-methylhistidine concentrations were determined with an AutoAnalyzer (Murray et al. 1982). Carcass protein concentrations were assayed after the whole carcass was powdered in solid carbon dioxide as described by Benville \& Tindle (1970). The sarcoplasmic, myofibrillar and collagen fractions were those sequentially extracted by $0.05 \mathrm{M}$-phosphate buffer (pH 7.4), $0.05 \mathrm{M}$-sodium hydroxide (Pennington \& Robinson, 1968) and $0.5 \mathrm{M}-\mathrm{NaOH}$ $\left(80^{\circ}, 3 \mathrm{~h}\right)$ respectively. A separate analysis of total non-collagen-protein (total soluble in $0.05 \mathrm{M}-\mathrm{NaOH}$ ) was also done, with all carcasses being analysed in the same manner and at the same time to avoid systematic differences between corticosterone-treated and untreated rats.

\section{Calculations}

The calculation of myofibrillar protein breakdown from the rate of excretion of $N^{\tau}$-methylhistidine was done as described earlier (Tomas, 1982). Briefly, it is assumed that $75 \%$ of the excreted $N^{\tau}$-methylhistidine arises from the carcass, that this proportion does not decrease on corticosterone treatment and that the $N^{\tau}$-methylhistidine content of the carcass myofibrillar protein remains virtually constant. Thus the average fractional rate of myofibrillar protein breakdown can be calculated as follows:

$$
\frac{N^{\top} \text {-Methis } \times 0.75}{\mathrm{NCP} \times 3.50} / \mathrm{d} \text {, }
$$

where $N^{T}$-Methis is the average excretion rate of $N^{\tau}$-methylhistidine $(\mu \mathrm{mol} / \mathrm{d})$ over the observation period, NCP is the average non-collagen-protein mass $(\mathrm{g})$ and 3.50 is the concentration of $N^{\top}$-methylhistidine in the carcass non-collagen-protein fraction $(\mu \mathrm{mol} / \mathrm{g}$ protein). Although based on the total non-collagen-protein fraction, the calculated turnover rates more accurately reflect those of the $N^{\top}$-methylhistidine-containing myofibrillar proteins and not the sarcoplasmic fraction. Since we have found the ratio, sarcoplasmic: myofibrillar protein remains remarkably constant under a range of dietary and hormonal treatments (sarcoplasmic protein 35.6 (SE 0.3 ) \% of non-collagen-protein), the myofibrillar protein pool parallels that of the total non-collagen-protein pool and thus the protein turnover values are directly applicable to the myofibrillar protein fraction. For Expt 1, the initial carcass non-collagen-protein content was estimated from the body-weight using values from the extra control groups. Thus, carcass non-collagen-protein was 7.28 and $6.96 \%$ of body-weight for high- and low-protein groups respectively (Table 2 , see p. 328). To obtain the final carcass non-collagen-protein content, carcass weight was estimated from its relationship to the gastrocnemius weight (carcass weight $=(33.97 \times$ gastrocnemius weight) $\left.+0.71 ; \mathrm{SE}_{\overline{\mathbf{Y}}_{\mathbf{X}}} 0.81, r 0.98, n 14\right)$ established in rats of $150-220 \mathrm{~g}$ body-weight which had been fed on high- and low-protein diets as in the experiment. Since the gastrocnemius protein content was unchanged by corticosterone treatment (Table 2), carcass noncollagen-protein concentration was assumed to be the same as determined in the extra control groups. To compare these methods, estimates can be made of final non-collagenprotein content of the carcasses from the two experimental groups which did not receive corticosterone. These estimates, based either on body-weight (as for initial carcass 
non-collagen-protein) or gastrocnemius weight, were 14.55 (SE 0.13) and 14.39 (SE 0.09) g for the high-protein group and 10.60 (SE 0.12) and 10.66 (SE 0.11 ) g for the low-protein group respectively. For Expt 2, final carcass non-collagen-protein was measured directly and initial carcass protein was extrapolated on a body-weight basis from measurements made on the control animals. In both experiments, carcass protein accretion rates before corticosterone treatment were calculated on the assumption that the non-collagen-protein $/ \mathrm{kg}$ body-weight was constant during the $3 \mathrm{~d}$ before treatment.

\section{Statistical analyses}

The results were analysed statistically by standard procedures for deriving Student's $t$ values and by analysis of variance. Least significant differences were calculated for $P=0.05$ from the pooled standard error of difference when analysis of variance showed a significant treatment effect. Due to the number of assumptions and cumulative errors in the calculation of protein synthesis rates, these values were not analysed statistically. Rather, they were compared on the basis of their qualitative changes.

\section{RESULTS}

Food intake, body- and organ-weights and composition

Food intakes are shown in Table 2. Match feeding was based on initial body-weight and consequently as group mean weights changed so also did the intake per unit body-weight. All food intakes were within the intended limits except for the high-intake group of Expt 2 which, instead of eating $50 \%$ more than controls, ate only 38 and $12 \%$ more before and during corticosterone treatment respectively. Thus this group ate the $62.5 \mathrm{~g}$ protein $/ \mathrm{kg}$ diet essentially $a d \mathrm{lib}$. and the protein:energy intake values relative to controls were $2 \cdot 2: 1 \cdot 4$ and 1.8:1.1 before and after treatment respectively. The control rats for Expts 1 and 2 receiving the $40 \mathrm{~g}$ protein $/ \mathrm{kg}$ diet $\mathrm{ad} \mathrm{lib}$. ate 83 and $100 \mathrm{~g}$ food $/ \mathrm{kg}$ body-weight respectively before treatment, and the difference is consistent with the smaller body-weight of the rats used in Expt 2. Diets containing $62.5 \mathrm{~g}$ protein $/ \mathrm{kg}$ promoted a $38 \%$ higher intake, indicating a limit to voluntary intake set by the lower protein intake.

Those groups which lost weight on the experimental diets showed the greatest decline in the first 7-10 d. Thereafter the $40 \mathrm{~g}$ protein $/ \mathrm{kg}$ groups either maintained or only slowly lost weight while the energy-restricted groups, which lost more weight initially, slowly gained in body-weight over the final 7-10 d period before corticosterone treatment. This explains the positive accretion rates in these groups at this time (Table 5, see p. 332).

Corticosterone treatment caused a fall in food intake in Expt 1 but an increase in Expt 2, and this may largely account for the differing responses in body-weight changes to the glucocorticoid in the low-protein groups. Rats receiving $220 \mathrm{~g}$ protein $/ \mathrm{kg}$ diet lost weight at four times the rate of those receiving $40 \mathrm{~g}$ protein $/ \mathrm{kg}$ following corticosterone injections of $30 \mathrm{mg} / \mathrm{kg}$ body-weight, but the fall in the gastrocnemius muscle mass relative to body-weight was similar. Both the weight and protein content of the liver were increased to a greater extent in the low-protein group by the corticosterone treatment (Table 2). Similarly, in Expt 2, an increase in the protein intake alone significantly diminished the rise in protein content of the liver in response to corticosterone injection, whereas variation in energy intake alone (constant protein) had little effect on this response. Diet appeared to have little influence on the final carcass weight relative to body-weight (Expt 2) except for a $5 \%$ reduction for the control group and a similar increase in the $95 \mathrm{~g}$ protein $/ \mathrm{kg}$ group (Table 2). However, the carcass protein concentration was less affected and thus the carcass non-collagen-protein mass reflected the carcass weights. Corticosterone treatment 


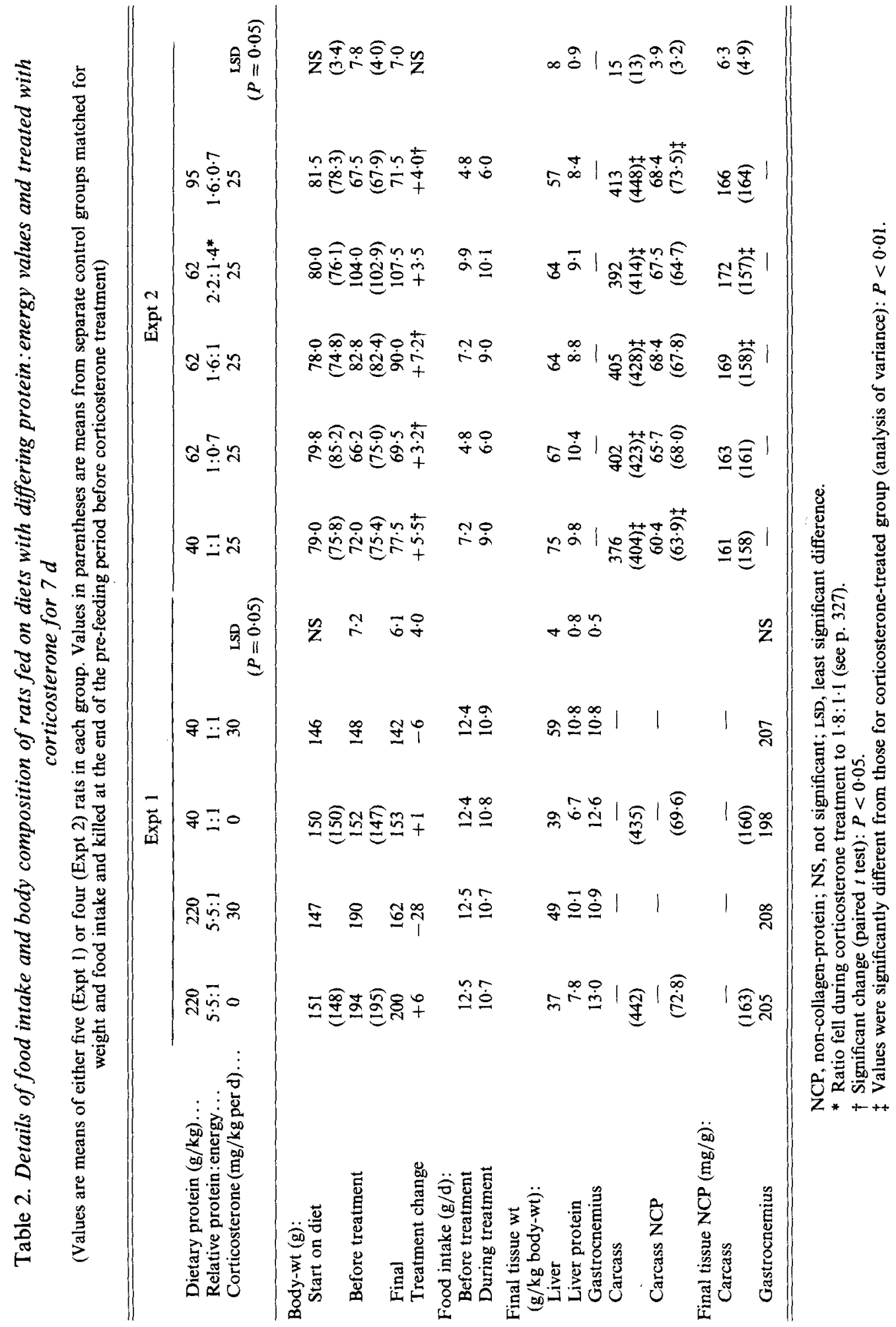




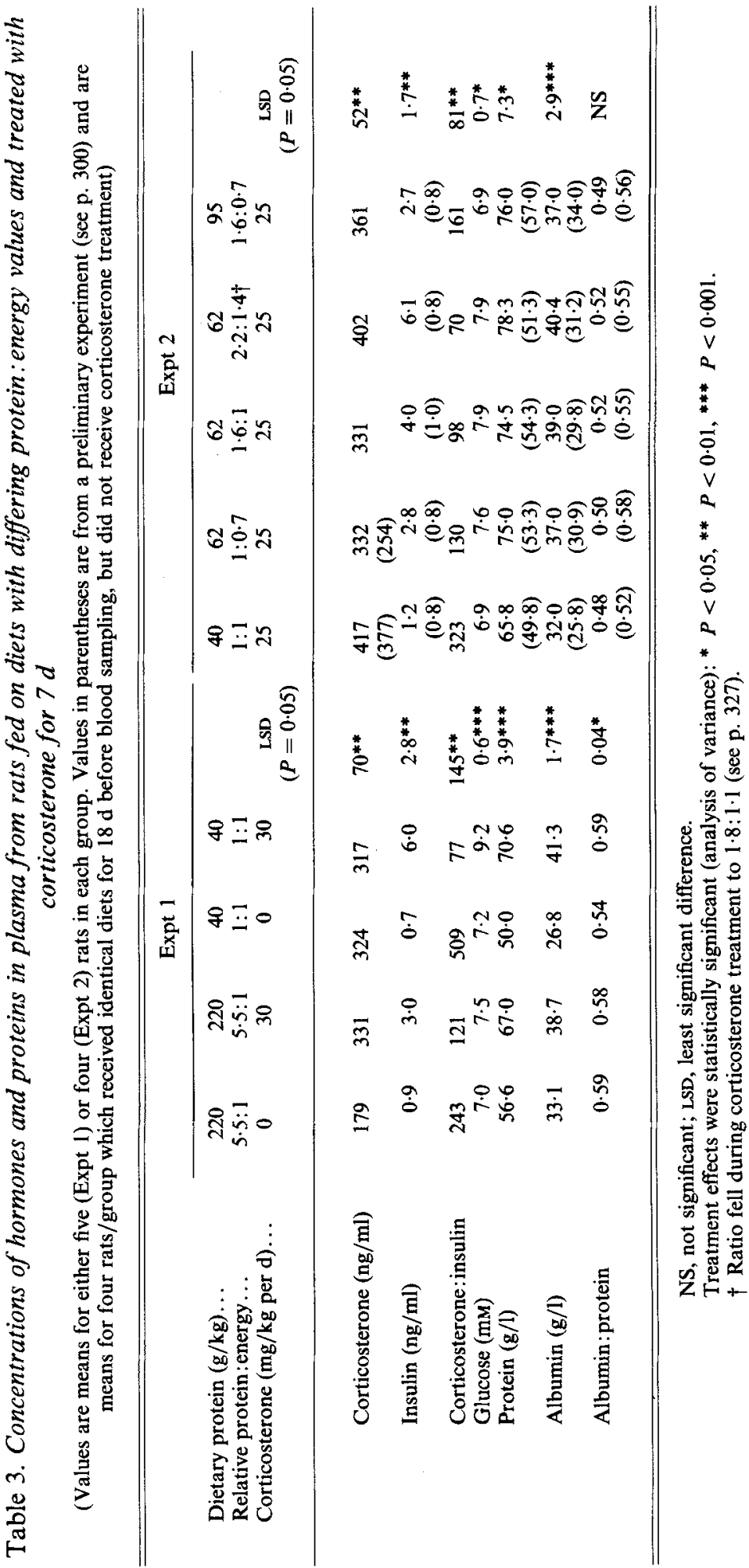


significantly decreased relative carcass weights but, as carcass protein concentrations were generally increased, there was little over-all change in carcass protein $/ \mathrm{kg}$ body-weight.

\section{Hormone and protein concentrations in plasma}

Values for plasma measurements are shown in Table 3. For purposes of comparison, values from a preliminary experiment virtually identical to Expt 2 are provided to indicate baseline values just before corticosterone treatment. Corticosterone concentrations in plasma were significantly increased by protein deficiency in untreated rats (Expt 1). Following corticosterone treatment there was no consistent effect of protein or energy intake on the corticosterone levels. Plasma insulin levels before treatment were similar in animals receiving either low- or high-protein diets, and corticosterone treatment caused a substantial rise of 2-8-fold in all diet groups. Although there were significant effects of diet within experiments, there was no consistent pattern of response between the experiments. The corticosterone:insulin values varied between 70 and 509 and inversely reflected the relative changes in plasma insulin concentrations.

Plasma albumin concentrations, and its proportion in total plasma protein, were significantly reduced in protein deficiency alone (Expt 1), but treatment with corticosterone markedly increased albumin concentrations in both deficient- and adequate-protein groups with little influence of the protein-energy content on the extent of the response.

\section{Urinary excretion of metabolites}

Daily urinary excretion of urea- $\mathrm{N}$, creatinine and $N^{7}$-methylhistidine before and after treatment of the rats with corticosterone are shown in Table 4. Corticosterone treatment significantly increased the loss of $\mathrm{N}$ as urea- $\mathrm{N}$ and the response was little modified by diet. For example, in Expt 1 the increase in urea-N was about $50 \%$ of ingested $\mathrm{N}$ whether rats received the 220 or $40 \mathrm{~g}$ protein $/ \mathrm{kg}$ diets, although the percentage change indicated a differential response. For Expt 2, where a lower dose of corticosterone was administered, the average increase in urea- $\mathrm{N}$ excretion was much less, generally less than $10 \%$ of ingested $\mathrm{N}$. However, the group which ate ad lib. the $62.5 \mathrm{~g}$ protein $/ \mathrm{kg}$ diet and which reduced its food intake during corticosterone treatment showed a marked increase in the excretion of urea-N. This increase was $2 \cdot 5-30$-fold greater than that for the other groups relative to $\mathrm{N}$ intake. Creatinine excretion was largely unaffected by corticosterone treatment in either experiment but was significantly increased by $11.6 \%$ in rats receiving a high-protein diet (Expt 1) and by 5.8 and $9.0 \%$ in rats receiving a restricted energy intake (Expt 2).

$N^{\top}$-Methylhistidine excretion relative to body-weight was decreased by $12 \%$ in rats receiving a low-protein diet and showing growth retardation (Expt 1). However, $N^{\tau}$ methylhistidine excretion was substantially increased by corticosterone treatment in all groups of rats and was directly related to the dose. Protein restriction reduced the increase from 90.5 to $56.8 \%$ in Expt 1, but the dietary perturbations in Expt 2 caused no significant difference in the increment in $N^{\tau}$-methylhistidine excretion during corticosterone treatment, albeit the energy-restricted rats showed a greater average increment.

\section{Myofibrillar protein turnover}

The average turnover rates of myofibrillar protein calculated from the average daily $N^{\tau}$-methylhistidine excretion rates and the changes in muscle non-collagen-protein mass are shown in Table 5. Due to some rates changing from positive to negative values following treatment, absolute rather than percentage changes are shown. As expected, the growth rate before glucocorticoid treatment was directly related to the dietary protein and energy intakes and ranged from near zero to $1.5 \% / \mathrm{d}$. The response to glucocorticoid treatment differed markedly between experiments. Rats receiving 220 and $40 \mathrm{~g}$ protein $/ \mathrm{kg}$ diet and 


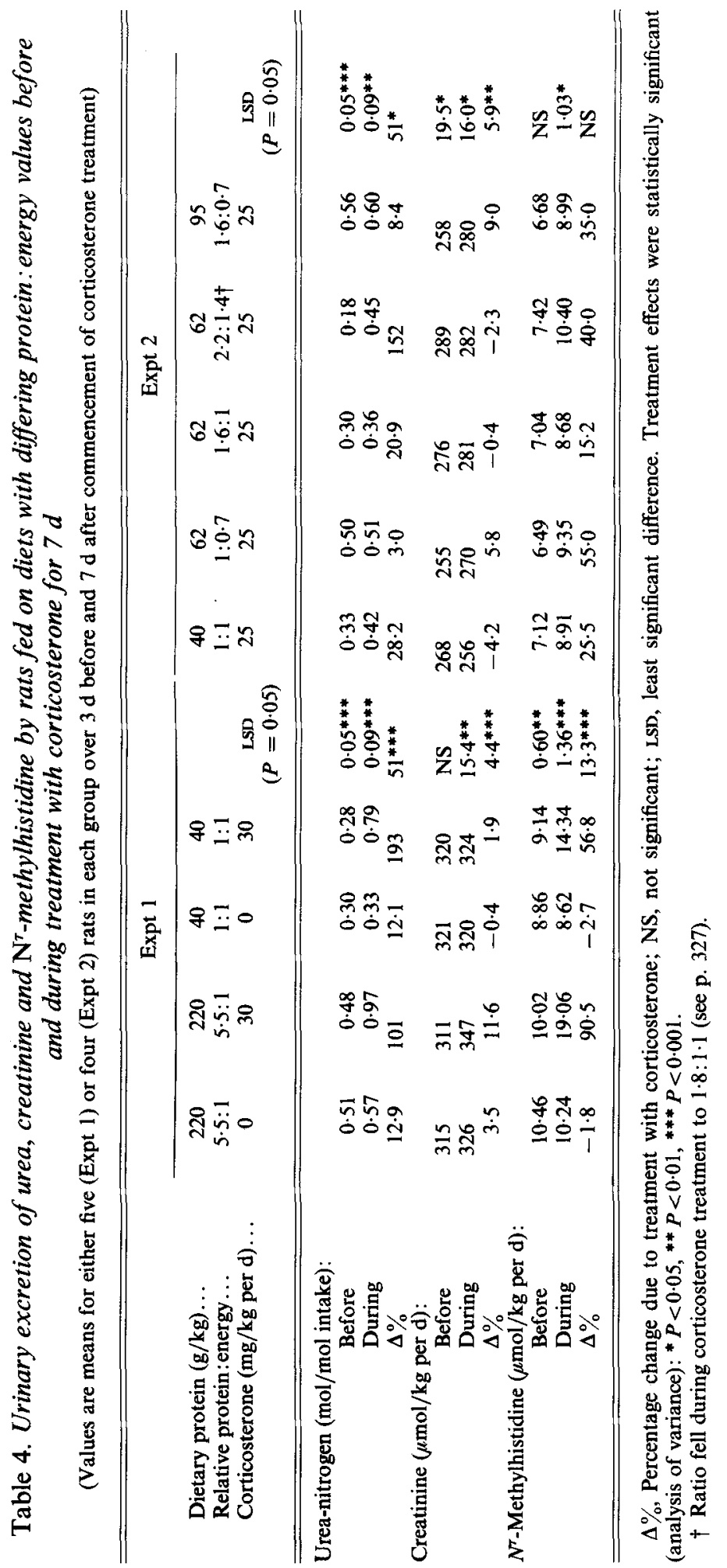




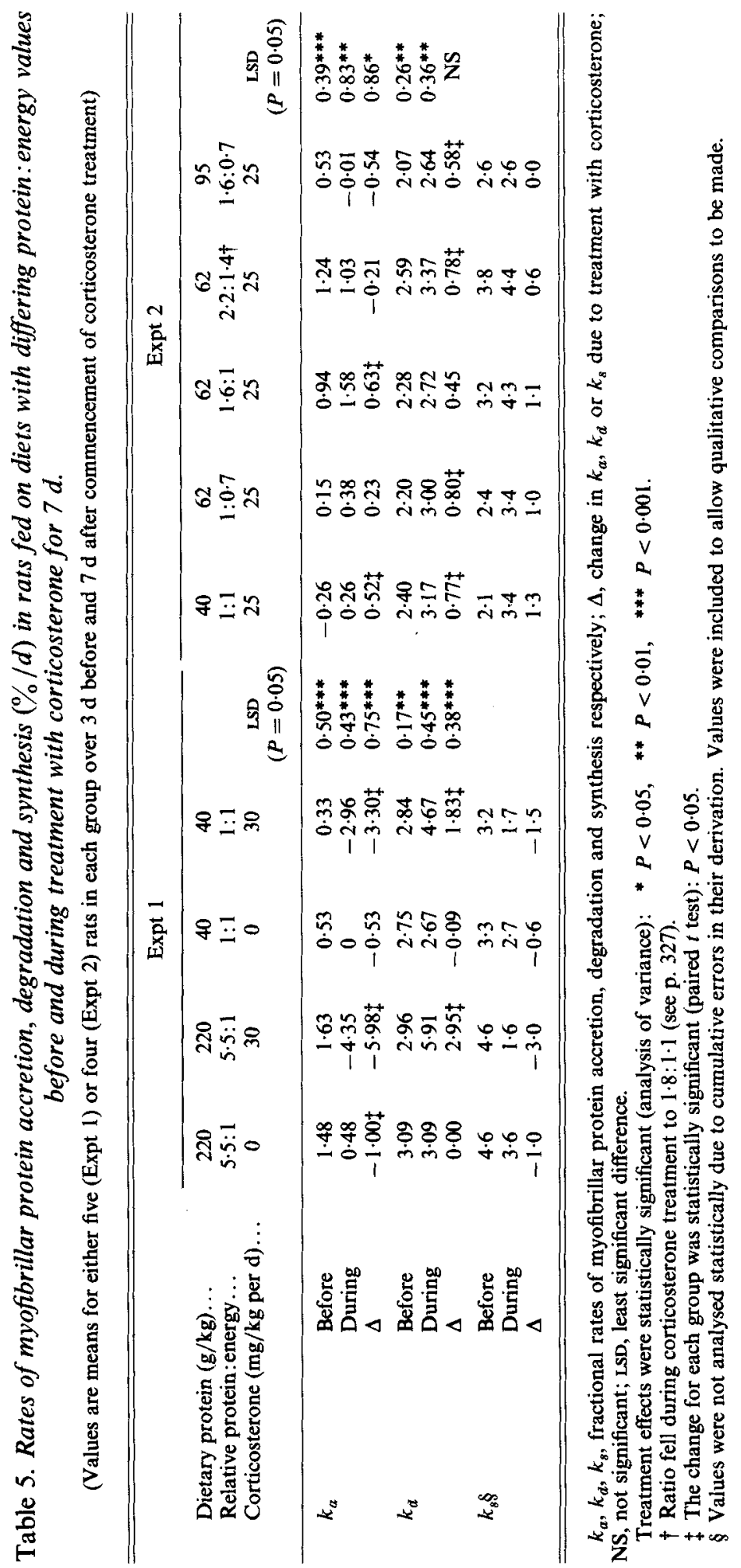


injected with $30 \mathrm{mg}$ corticosterone/ $\mathrm{kg}$ body-weight lost 4.4 and $3.0 \%$ non-collagen-protein $/ \mathrm{d}$ respectively, a highly significant change from the positive rates before treatment. Also these two rates of protein loss between dietary groups were significantly different. In contrast, administration of $25 \mathrm{mg}$ corticosterone $/ \mathrm{kg}$ led to either no significant change or a significantly increased protein accretion rate for different dietary groups in Expt 2 . Accretion rates did not change in those groups restricted in intake nor where intake fell during corticosterone treatment.

The fractional rates of myofibrillar protein breakdown $\left(k_{d}\right)$ were reduced by $10 \%$ with restriction of protein intake (Expt 1). Even lower rates were observed in Expt 2, where all protein intakes were relatively low, but the significant differences between dietary groups were due rather to the dietary energy intake than to protein intake. Protein breakdown rates were depressed by a decrease in energy intake. Treatment with corticosterone increased $k_{d}$ in all groups, the increase being three to four times greater for rats receiving $30 \mathrm{mg}$ steroid $/ \mathrm{kg}$ body-weight rather than $25 \mathrm{mg}$ steroid $/ \mathrm{kg}$ body-weight. However, although the low-protein diet reduced the effect of the glucocorticoid on $k_{d}$ in Expt $1(+1.83 v .+2.95 \% / \mathrm{d}$ for low-and high-protein diets respectively), there was no significant effect of the diet on the change in $k_{d}$ in Expt 2, where the average increment following treatment was $0.7 \% / \mathrm{d}$. Fractional synthesis rates $\left(k_{\delta}\right)$, calculated as the difference between accretion and breakdown, appeared to be influenced by both diet and glucocorticoid treatment. Synthesis rates generally were reduced by $30 \%$ or more by diets deficient in protein or energy, or both, compared with adequate diets. In Expt 2, synthesis rates were about $40-50 \%$ higher in the two groups receiving the highest levels of protein and energy $(62.5 \mathrm{~g}$ protein $/ \mathrm{kg}$ at 1 and 1.5 times isoenergetic levels) compared with other groups both before and after corticosterone treatment. Corticosterone substantially reduced calculated synthesis rates in Expt 1, regardless of protein intake, but the average $k_{s}$ values were increased in all groups in Expt 2. This apparent increase in $k_{s}$ was due to protein accretion rates being maintained or increased despite the increase in $k_{d}$ following hormone treatment.

\section{DISCUSSION}

These results show that rats accustomed to a protein-deficient diet are less affected in respect of carcass protein catabolism than are adequately fed animals by the administration of exogenous corticosterone. This is at variance with the observations of Goodlad \& Munro (1959) and Santidrian et al. (1981). Although the weight losss and increase in $N^{r}$. methylhistidine excretion caused by the treatment were significantly less for protein-deficient animals, the changes in organ weights and plasma proteins were similar for each dietary group. In addition, the proportion of $\mathrm{N}$ intake excreted as urea was lower in rats receiving the low-protein diet than in rats receiving the high-protein diet, both before and during corticosterone treatment (Table 4). Thus, although the protein-deficient animals mobilized less muscle protein in response to the glucocorticoid treatment, they appeared to utilize more efficiently those extra amino acids made available from muscle for the synthesis of other proteins. This may in part be due to the relatively higher plasma insulin concentrations which were induced by the corticosterone treatment in this group (Table 3), since it has been shown that this secondary rise in insulin counteracts the catabolic effect of the steroid on muscle (Tomas, 1982). Replenishment of liver and plasma protein in protein-deficient rats could also play a role. While total liver protein remained virtually unchanged in the high-protein group (+75 mg, Expt 1), $500 \mathrm{mg}$ protein was accumulated in the livers of the low-protein group during corticosterone treatment compared with untreated controls (Table 2) and represented about $20 \%$ of the net loss of protein from muscle.

Despite the benefits of corticosterone treatment such as the improvement in plasma 
protein levels, the mobilization of muscle protein in Expt 1 caused a net loss of $\mathrm{N}$ and hence, presumably, decreased the animals' viability. Similar results were reported by Lunn et al. (1976), who used smaller rats and a lower dose of glucocorticoid. Thus, in the longer term, survival of the animals probably would not be enhanced by this level of corticosteroid treatment.

In the second experiment, the control rats receiving $40 \mathrm{~g}$ protein $/ \mathrm{kg}$ diet responded to glucocorticoid treatment with an increase in ad lib. intake of food, not a decrease as in Expt 1 . There is no obvious reason for this difference, particularly as the animals already had a higher intake relative to body-weight. The differing age, stage of growth of the rats or dose rate of corticosterone may be the basis for the difference. However, the liver and plasma proteins showed the usual response to corticosterone and were elevated above normal. The unusual and unexpected increase in growth rate (protein accretion) and the calculated synthesis rates which were observed, despite an increase in the myofibrillar protein degradation rate, may have stemmed from the increase in food intake. Such a proposal was also made by Odedra \& Millward (1982) to explain differences between their results using ad lib.-fed rats and those of Tomas et al. (1979). Interestingly, the groups which did not show a significant increase in protein accretion rates were those receiving restricted energy intake and the group which did not show a sustained increase in intake $(62.5 \mathrm{~g}$ protein $/ \mathrm{kg}$, ad lib.) following treatment. Thus, although analysis of variance shows only one of the changes in accretion rate to be different from the others $(95 \mathrm{~g}$ protein $/ \mathrm{kg}$ group) these results are at variance with the conclusions of Goodlad \& Munro (1959) that dietary energy and protein levels do not influence the catabolic effects of glucocorticoids given at moderate dose levels.

The apparent increase in synthesis rates during corticosterone treatment in Expt 2 is difficult to explain. Almost all reported studies on the effect of glucocorticoids on muscle protein turnover have reported a decrease in muscle protein synthesis rates, and that the synthetic processes are more sensitive to glucocorticoids than are those for the breakdown of muscle proteins (Millward et al. 1976 $a, b$; Shoji \& Pennington, 1977; Rannels \& Jefferson, 1980; Odedra \& Millward, 1982). There is little basis to doubt the validity of our carcass non-collagen-protein accretion measurements, albeit initial values are based (unavoidably) on an extrapolation from identically fed untreated controls. Certainly all the animals gained body-weight during treatment. A similar increase in apparent synthesis rates was also observed in a preliminary experiment with virtually identical diets and treatments. One potential source of error may, however, arise from alteration in the proportions of $N^{\top}$-methylhistidine arising from skeletal muscle or from other sources (Bates \& Millward, 1981 ), but this seems unlikely. If there were no change in myofibrillar protein degradation rate with glucocorticoid treatment (i.e. in line with the results of Rannels \& Jefferson (1980), Kelly \& Goldspink (1982), McGrath \& Goldspink (1982)) in Expt 2, then for the low-protein control group the extra $1.8 \mu \mathrm{mol} N^{\tau}$-methylhistidine/ $\mathrm{kg}$ body-weight per $\mathrm{d}$ would need to arise from non-skeletal muscle sources. The gut serosa would be a likely source (Wassner $\& \mathrm{Li}, 1982$ ). Kelly \& Goldspink (1982) found no change in the fractional synthesis rate of proteins in the intestinal serosa following treatment of rats with dexamethasone at a dose equivalent to $100 \mathrm{mg}$ corticosterone $/ \mathrm{kg}$ (four times the dose rate used in the experiment reported here), but the protein mass declined by $9.5 \% / \mathrm{d}$. Thus, the extra $N^{\tau}$-methylhistidine released could be as much as $10 \%$ of the gut pool/d, or about $0 \cdot 1 \mu \mathrm{mol} / \mathrm{d}$ for a $100 \mathrm{~g}$ rat (Millward et al. 1980), about half the observed increase. Furthermore, in a recent experiment using a similar regimen to that reported here, we did not find any change in gut serosal protein content following corticosterone treatment (values not shown). As the skin appears to contribute little to $N^{\tau}$-methylhistidine excretion (Wassner \& $\mathrm{Li}, 1982$ ), myofibrillar protein breakdown in skeletal muscles of our rats seems more likely to have increased 
than to have declined or remained constant. Thus, corticosterone treatment caused an apparent anabolic response by muscle in this experiment with over-all average increases in accretion, synthesis and breakdown. The reasons for this are obscure, but may be related to the change in either intake or corticosterone:insulin values (Odedra \& Millward, 1982; Tomas, 1982). The differential effects of the energy-restricted groups on protein accretion rates argue that the change in food intake was an important factor.

The metabolism of nutrients by a tissue is determined by a number of mechanisms, such as nutrient supply, organ function and the balance of hormonal influences. Of the latter, the balance of glucocorticoids and insulin, the principal catabolic and anabolic hormones, is of major importance (e.g. Tischler, 1981). One weakness in the design of experiments using exogenous glucocorticoid administration is the accompanying increase in circulating insulin concentrations in plasma (Lunn et al. 1976; Millward et al. 1976a, b; Tomas et al. 1979; Tomas, 1982) which is evident in the experiments reported here (Table 3 ). While it has been postulated that corticosterone: insulin values, rather than absolute concentrations, may be important in determining the direction of metabolism (e.g. Tischler, 1981), others have found that insulin is unable to reverse the glucocorticoid inhibition of muscle protein synthesis (Odedra \& Millward, 1982) and can only partially buffer the increase in myofibrillar protein breakdown (Tomas, 1982). Analysis of the results presented by Lunn et al. (1976) shows that from day 4 to day 15 of either glucocorticoid or vehicle injection to protein-deficient rats, the corticosterone:insulin values for each group were essentially the same (mass ratio approximately 470 ). In contrast, the ratios observed in this experiment varied widely between treatment groups and, furthermore, appear to be related to the changes in myofibrillar protein turnover. The two groups showing the highest accretion and synthesis rates during corticosterone treatment had significantly higher insulin and lower corticosterone:insulin values in the plasma. Such a relationship was also seen in Expt 1, but with insulin in an anti-catabolic role. However, a single daily plasma sample may be inadequate to determine with confidence whether such a relationship exists since the $24 \mathrm{~h}$ pattern may differ between treatment groups. This could arise from the differing extents of food restriction which are superimposed on the nutritional status (Gallo \& Weinberg, 1981). Also, an apparent relationship may not indicate metabolic modulation, since the energy status of the rat at a particular time may determine whether the prevailing corticosterone and insulin levels are anabolic or catabolic in their effects (Griffin \& Wildenthal, 1978; Goldberg et al. 1980). None the less, the results do indicate that the circulating insulin levels may be determining the response to some extent.

In our calculations we have assumed that $75 \%$ of the excreted $N^{\tau}$-methylhistidine originates from skeletal muscle proteins and that this percentage does not change with glucocorticoid treatment. The reasons for these assumptions have been discussed previously (Tomas, 1982) and, in view of the apparent sensitivity of the skeletal muscle actin breakdown rate to glucocorticoids (Odedra et al. 1980), the assumption that the percentage arising from muscle is at least not decreased by treatment seems reasonable. As discussed previously, the possibility that gut serosal protein turnover may be increased by the treatments used here cannot be ruled out, particularly in view of the apparent dependence of the protein synthesis rates on the dietary protein supplies (McNurlan \& Garlick, 1981). Because of these, and the several other assumptions involved in our calculations such as estimation of body composition, more emphasis should be placed on the comparative rather than the quantitative aspects of the calculated protein turnover values, especially with regard to the fractional synthesis rates of myofibrillar protein. This is consistent with the approach used by others to similar findings (Burini et al. 1981; Santidrian et al. 1981; Dunn et al. 1982).

The rat is regarded as a poor model for protein-deficiency studies in humans (Whitehead, 1980), due in part to its restriction of food intake and raised plasma 3,5,3'-triiodothyronine 
levels when fed on low-protein diets (e.g. Edozien et al. 1978). In our studies protein deficiency did, however, lead to lowered plasma albumin and insulin concentrations, decreased liver protein and elevated plasma corticosterone levels, features common to the marasmic sequelae of malnutrition (Coward \& Lunn, 1981). Muscle protein turnover was also depressed, as found by others in both humans and rats (Nagabhushan \& Narasinga Rao, 1978; Millward, 1979). Administration of corticosterone reversed these features, but the cost was a reduction in the utilization of the dietary $\mathbf{N}$, most marked in Expt 1, where weight loss and relative muscle wasting occurred. The findings from the two experiments indicate, first, that protein deficiency decreases the catabolic effects of glucocorticoids and second, depending on nutritional state and hormone dosage level, that glucocorticoids may also be 'anabolic' in muscle of protein-deficient animals. Thus, caution should be used when particular metabolic consequences are ascribed on the basis of circulating hormone levels, particularly in malnutrition states.

In contrast to our results, Santidrian et al. (1981) found energy and protein-energy-deficient rats to be more sensitive to glucocorticoids than were protein-deficient or control rats. However, their experiment was similar to that reported by Goodlad \& Munro (1959), and their rats were not pre-fed on the experimental diets so that the glucocorticoid treatment coincided with a sudden severe reduction in energy intake. Thus their experiments were not comparable with ours except that they emphasize the apparent importance of a fall in energy intake, such as occurred in Expt 1, on the response to glucocorticoid treatment. In addition, well-fed growing rats may have a different proportion of 'red' and 'white' muscle fibres in the carcass, compared with rats adapted to deficient diets and in growth stasis. Since different muscle types respond differently to glucocorticoids (Kelly \& Goldspink, 1982), this may also account for some of the apparent discrepancies between experiments. In fact, a possible explanation for the decreased sensitivity of muscle to glucocorticoids in proteinenergy-deficient states is a preferential wasting of the more sensitive white muscle fibres before treatment.

Although glucocorticoids can be shown to cause protein loss from muscle and protein gain by the liver (Expt 1; Lunn et al. 1976) in protein-deficient animals, thus enhancing the typical marasmic pattern of metabolism, the net result is an accelerated weight loss, at least where food intake falls or remains restricted. The decreased effectiveness of glucocorticoids to increase muscle protein breakdown and net muscle loss in protein-deficient animals, where muscle protein turnover is already depressed (e.g. Millward, 1979; Rikimaru et al. 1980; present results, Table 5), indicates that care should be taken in interpreting the physiological significance of the elevated cortisol levels found in human infants suffering from protein-energy malnutrition (Lunn et al. 1973; Olusi et al. 1977; Whitehead \& Lunn, 1979). Our finding, that administered corticosterone can lead to an anabolic response by rats restricted in protein and energy intake, in spite of an apparent increase in myofibrillar protein degradation rate, is a novel one and raises further questions concerning the interactions between nutrient supply and hormonal effects on metabolic processes. The mechanisms for this apparent anomalous response deserve further study.

\section{REFERENCES}

Bates, P. C. \& Millward, D. J. (1981). Proceedings of the Nutrition Society 40, 89 A.

Benville, P. E. \& Tindle, R. C. (1970). Journal of Agricultural and Food Chemistry 18, 948-949.

Burini, R., Santidrian, S., Moreyra, M., Brown, P., Munro, H. N. \& Young, V. R. (1981). Metabolism-Clinical and Experimental 30, 679-687.

Coward, W. A. \& Lunn, P. G. (1981). British Medical Bulletin 37, 19-24.

Dorsey, T. E., McDonald, P. W. \& Roels, O. A. (1977). Analytical Biochemistry 78, 156-164.

Dunn, M. A., Houtz, S. K. \& Hartsook, E. W. (1982). Journal of Nutrition 112, 1862-1875.

Edozien, J. C., Niehaus, N., Mar, M.-H., Makoui, T. \& Switzer, B. R. (1978). Journal of Nutrition 108, $1767-1776$.

Gallo, P. V. \& Weinberg, J. (1981). Journal of Nutrition 111, 208-218. 
Goldberg, A. L., Tischler, M., DeMartino, G. \& Griffin, G. (1980). Federation Proceedings 39, 31-36.

Golden, M. H. N. (1982). Lancet 1, 1261-1265.

Goodlad, G. A. J. \& Munro, H. N. (1959). Biochemical Journal 73, 343-348.

Griffin, E. E. \& Wildenthal, K. (1978). American Journal of Physiology: Endocrinology and Metabolism 3, E306-E313.

Jaya Rao, K. S. (1974). Lancet i, 709-711.

Kelly, F. J. \& Goldspink, D. F. (1982). Biochemical Journal 208, 147-151.

Lowry, O. H., Rosebrough, N. J., Farr, A. L. \& Randall, R. J. (1951). Journal of Biological Chemistry 193, 265-275.

Lunn, P. G., Whitehead, R. G., Baker, B. A. \& Austin, S. (1976). British Journal of Nutrition 36, 537-550.

Lunn, P. G., Whitehead, R. G., Hay, R. W. \& Baker, B. A. (1973). British Journal of Nutrition 29, 399-422.

McGrath, J. A. \& Goldspink, D. F. (1982). Biochemical Journal 206, 641-645.

McNurlan, M. A. \& Garlick, P. J. (1981). American Journal of Physiology: Endocrinology and Metabolism 4, E238-E245.

Millward, D. J. (1979). Proceedings of the Nutrition Society 38, 77-88.

Millward, D. J., Garlick, P. J., Nnanyelugo, D. O. \& Waterlow, J. C. (1976a). Biochemical Journal 156, 185-188.

Millward, D. J., Nnanyelugo, D. O., Bates, P. \& Head, C. R. C. (1976b). Proceedings of the Nutrition Society 35, $47 \mathrm{~A}$.

Millward, D. J., Bates, P. C., Grimble, G. K., Brown, J. G., Nathan, M. \& Rennie, M. J. (1980). Biochemical Journal 190, 225-228.

Murray, A. J., Ballard, F. J. \& Tomas, F. M. (1982). Analytical Biochemistry 116, 537-544.

Nagabhushan, V. S. \& Narasinga Rao, B. S. (1978). American Journal of Clinical Nutrition 31, 1322-1327.

Odedra, B., Bates, P. C., Nathan, M., Rennie, M. \& Millward, D. J. (1980). Proceedings of the Nutrition Society $39,82 \mathrm{~A}$.

Odedra, B. \& Millward, D. J. (1982). Biochemical Journal 204, 663-672.

Olusi, S. O., Orrell, D. H., Morris, P. M. \& McFarlane, H. (1977). Clinica Chimica Acta 74, 261-269.

Pennington, R. J. \& Robinson, J. E. (1968). Enzymologia Biologica et Clinica 9, 175-182.

Rannels, S. R. \& Jefferson, L. S. (1980). American Journal of Physiology: Endocrinology and Metabolism 1, E 564-E 572.

Rikimaru, T., Yamamoto, S., Maeda, K. \& Inoue, G. (1980). Journal of Nutritional Science and Vitaminology 26, 39-57.

Rogers, Q. R. \& Harper, A. E. (1965). Journal of Nutrition 87, 267-273.

Santidrian, S., Moreyra, M., Munro, H. N. \& Young, V. R. (1981). Metabolism-Clinical and Experimental 30, 798-804.

Shoji, S. \& Pennington, R. J. (1977). Molecular and Cellular Endocrinology 6, 159-169.

Smith, I. F., Latham, M. C., Azubuike, J. A., Butler, W. R., Phillips, L. S., Pond, W. G. \& Enwonwu, C. O. (1981). Proceedings of the Society for Experimental Biology and Medicine 167, 607-611.

Technicon Instruments Co. Ltd (1965). Technicon Methodology Sheet N-1 l b. Basingstoke: Technicon Instruments Co. Ltd.

Technicon Instruments Co. Ltd (1967). Technicon Methodology Sheet N-1c. Basingstoke: Technicon Instruments Co. Ltd.

Tischler, M. E. (1981). Life Sciences 28, 2569-2576.

Tomas, F. M. (1982). Biochemical Journal 208, 593-601.

Tomas, F. M., Munro, H. N. \& Young, V. R. (1979). Biochemical Journal 178, 139-146.

Wassner, S. J. \& Li, J. B. (1982). American Journal of Physiology: Endocrinology and Metabolism 6, E293-E297.

Waterlow, J. C., Garlick, P. J. \& Millward, D. J. (1978). Protein Turnover in Mammalian Tissues and in the Whole Body. Amsterdam: North Holland.

Webster, D. (1977). Clinical Chemistry 23, 663-665.

Whitehead, R. G. (1980). Proceedings of the Nutrition Society 39, 227-231.

Whitehead, R. G. \& Lunn, P. G. (1979). Proceedings of the Nutrition Society 38, 69-76. 